\title{
POLLEN ANALYSIS AND DISCUSSION OF TIME-SCALES IN CANADIAN ICE CORES
}

\author{
by \\ R.M. Koerner and J.C. Bourgeois \\ (Terrain Sciences, Geological Survey of Canada, 601 Booth Street, Ottawa K1A 0E4, Canada) \\ and \\ D.A. Fisher \\ (Department of Glaciology, Geophysical Institute, University of Copenhagen, \\ Haraldsgade 6, DK -2200 Copenhagen N, Denmark)
}

\begin{abstract}
Previous pollen analyses of ice cores from Devon and Ellesmere islands have contributed considerably to our knowledge of past climate in the Canadian High Arctic. In this case, in 1979, bulk (35-83 litres) water samples were melted down a hole $139 \mathrm{~m}$ deep, drilled to bedrock, $1.2 \mathrm{~km}$ from the top of the flow line in Agassiz Ice Cap in northern Ellesmere Island. Analysis of ten of these samples, plus some taken in very dirty ice from the melt tank during drilling 7 years ago, has yielded pollen concentrations that, together with the oygen-isotope (ס) signatures, suggest the Agassiz Ice Cap began its growth during the last interglacial period. A discrepancy between melt-tank and bulk-sample pollen concentrations is believed to be due to a loss of pollen from the melt-tank samples during the drilling process.
\end{abstract}

\section{INTRODUCTION}

Cores drilled from surface to bedrock at the tops of Devon Island ice cap and Agassiz Ice Cap (Table I) all show three major oxygen-isotope ( $\delta$ ) stages. These are shown on the $\delta$ profile from the A79 core. We use this core for reference, as it is closer to the top of its flow line than the other three (Table I). Its ice has therefore suffered less deformation, so that its climatic record is the least disturbed of the four cores. The same general sequence also appears in the much deeper surface-to-bedrock cores from Camp Century and Dye 3 in Greenland (Dansgaard and others 1982). The upper two sections (A and B in Fig.1) have unequivocally been considered in all cases as Holocene (A) and Wisconsinan (B) in age. Identification of the origin of section $C$ is less certain. The upper boundary of the approximately equivalent section $\mathrm{C}$ in the Camp Century core was originally dated at $65 \mathrm{ka}$ (Johnsen and others 1972) and, by alignment with the same core, Paterson and others (1977) assumed the same date for the upper boundary of the same section in the D72 and D73 cores from Devon Island ice cap (Table I). Comparison with ocean cores (e.g. oxygen-isotope stages (OIS) $1-6$ in Ruddiman and others (1980) and Shackleton and Opdyke (1973)) suggested an early glacial-period (OIS 5a, b and c) origin for this section, as sea-levels were lower than today. Thus Paterson and others (1977) attributed the rather interglacial-like $\delta$ values of the section in the D72 and D73 cores to snow deposition from a different vapour source from today. However, by comparing the shape of the $\delta$ curve in the Camp Century core with that from ocean cores, Dansgaard and others (1982) changed the date of the top of section C to $113 \mathrm{ka}$. This would give the ice in that section a full interglacial origin.

From pollen analysis of melt-tank samples generated during thermal drilling of the D73 core, McAndrews (1984) considered that section $\mathrm{C}$ in that core was interglacial. However, because the sample resolution is so poor and the pollen totals are so low this is not a statistically strong conclusion. Koerner and Fisher (1985), by associating the D73 pollen data with ice texture and $\delta$ values, attributed an interglacial origin to only the lowermost $700 \mathrm{~mm}$ of the D73 core. Bourgeois (1986), in a discussion of pollen concentrations in the A77 core but with the same problems of low pollen totals, questioned whether there was any pre-Wisconsin ice at all in that core. Koerner and others (1987) equated section C both in the A77 and A79 cores (Fig.1) with OIS 5. They did not attribute a sub-stage, such as interglacial stage $5 \mathrm{e}$, to any part of the record.

Section $D$ in Figure 1 consists of very dirty ice. This section does not appear in the Devon Island ice cap cores or the A77 core. The section may well be contemporaneous with the dirty ice just above the bed both in the Camp Century (Herron and Langway 1979) and the Dye 3 (Dansgaard and others 1982) cores. In a study of this section in the A79 core, Gemmell and others (1986) considered that as the particles are too large to have been blown on to the ice and show no signs of abrasion, their incorporation in the ice was due to a melt/freeze-on process. Koerner and others (1987) further argued that the melt/freeze-on process must have occurred during flow

TABLE I. BORE-HOLE DATA

$\begin{array}{lcccccccc}\text { Location } & \text { Core no. } & \begin{array}{c}\text { Elevation } \\ \mathrm{m} \text { a.s.1. }\end{array} & \begin{array}{c}\text { Year } \\ \text { drilled }\end{array} & \begin{array}{c}\text { Distance down } \\ \text { flow line } \\ \mathrm{km}\end{array} & \begin{array}{c}20 \mathrm{~m} \text { temp. } \\ { }^{\circ} \mathrm{C}\end{array} & \begin{array}{c}\text { Basal temp. Surface-to-bed } \\ { }^{\circ} \mathrm{C}\end{array} & \begin{array}{c}\text { Snow } \\ \text { core length }\end{array} \\ \begin{array}{l}\text { Devon Island } \\ \text { ice cap }\end{array} & \mathrm{D} 72 & 1800 & 1972 & 10 & -23.4 & -18.4 & 299 & 0.22 \\ \text { rate } \mathrm{m} / \mathrm{w} . \mathrm{e} .\end{array}$




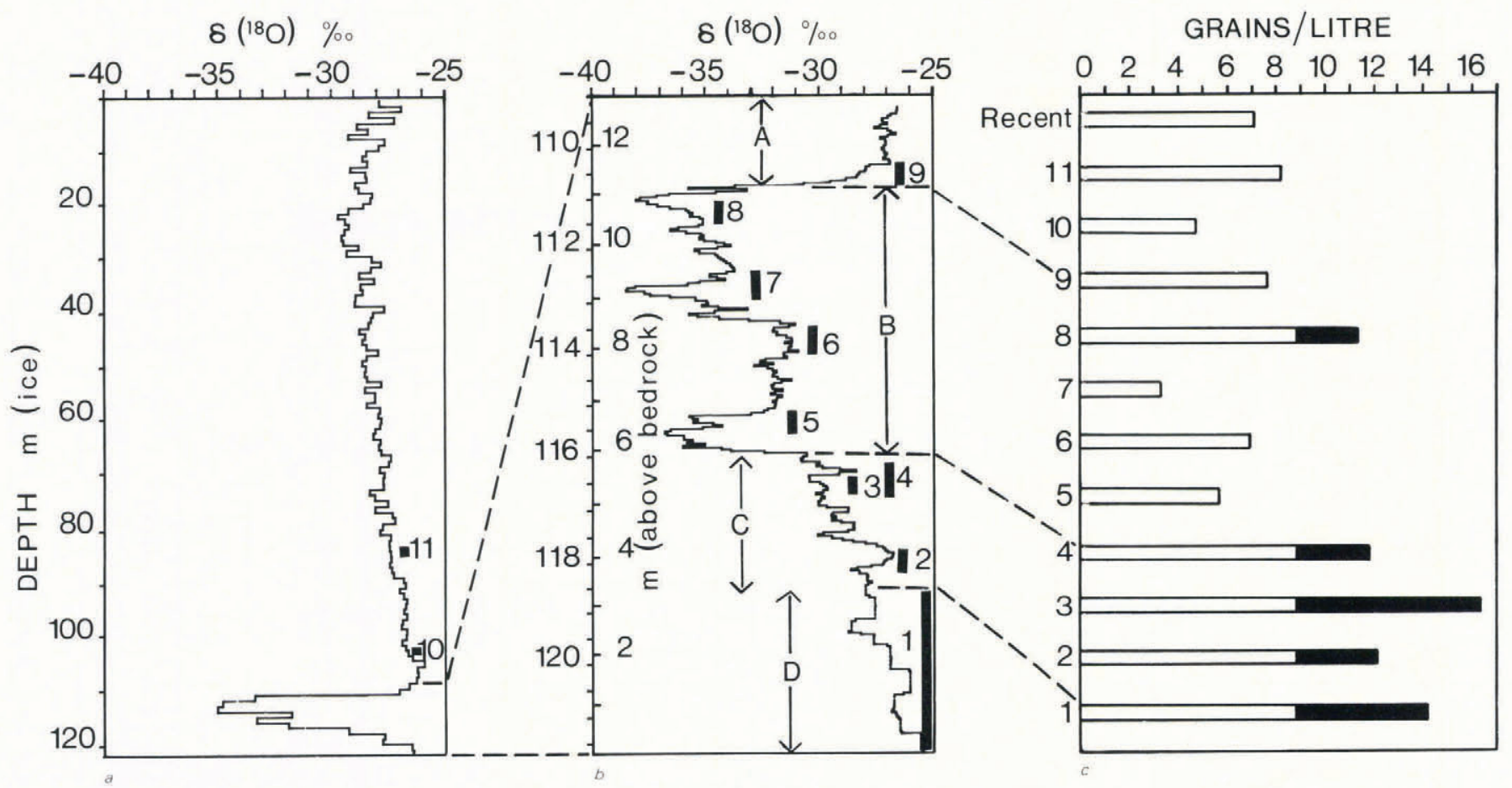

Fig.1. Oxygen-isotope $\left(\delta^{18} \mathrm{O}\right)$ and pollen concentrations from the 1979 Agassiz Ice Cap (Ellesmere Island) core. (a) Plotted on an ice-equivalent depth scale. (b) Plotted as metres of ice above the bed. (c) Pollen concentrations plotted by sample number. With the exception of no.l (see text) the numbered bars in (a) and (b) refer to the bulk-sample increments. The uppermost sample in (c) is from four $5 \mathrm{~m}$ cores collected in 1983. In (c) values above the mean are shaded.

over a deep valley up the flow line. As the present flow line begins about $1 \mathrm{~km}$ up-slope of the A79 site, the ice must have been thicker and had quite different flow lines at some time in the past. Suitable basal conditions for this process are most likely to have occurred as the area emerged from the Illinoian glacial period (OIS 6) and entered the Sangamon interglacial (OIS 5e). The former would promote thicker ice and the latter warmer atmospheric conditions. Both situations combined to effect the required basal conditions. However, the basal ice would be relic ice, contemporary with the Illinoian glacial period.

The main questions at this stage were first whether section $\mathrm{C}$ in the Devon Island and Agassiz Ice Cap cores is early glacial- or fully interglacial-period ice, and secondly whether the dirty basal ice in section $D$ is due to freeze-on of basally melted Illinoian-period ice. Pollen studies, although they had given climatic insight into the Holocene (A) section of our cores, had contributed very little below that, i.e. in the pre-Holocene ice. Yet they seemed to be the only method available which was capable of answering these two questions. Previous studies of pollen concentrations in the deepest ice had suffered from very poor time-depth resolution and low pollen concentrations. At these levels in our cores $1 \mathrm{~cm}$ represents more than 100 years. With pollen concentrations sometimes <l grain/litre, one melt-tank increment, representing $>15 \mathrm{ka}$, might yield as few as ten pollen grains. We therefore needed samples from much smaller time-depth increments but, more importantly, with total pollen sums of over 100 grains. The only way to produce such samples is by bulk melting, down pre-existing bore holes. This paper describes the methods and discusses the results of our work.

\section{METHODS}

Previous pollen studies of ice cores were done via melt-tank water produced during the process of thermal drilling. Maximum resolution was a single ice-core increment $(1.5 \mathrm{~m})$ which spans a few years near the surface but thousands of years near the bed. Furthermore, because pollen concentrations are so low (a few pollen grains per 15 litres of melt water, which represents one core increment), several core increments of melt-tank water are needed to provide a pollen spectrum. In pre-Holocene ice the resultant resolution is equivalent almost to an entire ice age! Thus a new method, capable of producing 30-100 litres of uncontaminated melt water for depth increments as small as $\mathbf{2 0 0}-\mathbf{3 0 0} \mathrm{mm}$, was clearly needed. A method was designed for application in the Agassiz Ice Cap 1979 bore hole, which penetrates to the glacier bed and is close to the top of a flow line. In the field seasons of 1984, 1985 and 1986, bulk samples were taken from ten different depth levels in this hole (Table II).

\section{Field}

The first requisite for melting bulk samples at any level is to form an impervious plug at that level. Methods for gas extraction developed by the Swiss and used for ${ }^{14} \mathrm{C}$ dating in the 1973 Devon Island bore hole (Paterson and others 1977) used inflatable balloons as plugs. As these were not available and we were working towards the bottom of a relatively shallow bore hole, we refilled the hole with refrozen melt water from the Agassiz Ice Cap 1977 drilling operation. This water had already been filtered and was

\section{TABLE II. POLLEN-SAMPLE LOG.}

Sample Depth * Litres Total pollen Concentration ( $\mathrm{m}$ above bedrock)

$\begin{array}{lcccr}\text { Recent } & \text { ** } & 77.8 & 555 & 7.1 \\ 11 & 54.0-54.5 & 30.6 & 251 & 8.2 \\ 10 & 37.5-38.0 & 34.5 & 160 & 4.6 \\ 9 & 11.3-11.8 & 37.3 & 282 & 7.6 \\ 8 & 10.3-10.7 & 39.2 & 419 & 10.7 \\ 7 & 8.9-9.5 & 36.7 & 121 & 3.3 \\ 6 & 7.9-8.4 & 33.9 & 236 & 6.9 \\ 5 & 6.2-6.8 & 31.7 & 185 & 5.8 \\ 4 & 5.0-5.6 & 83.6 & 984 & 11.8 \\ 3 & 5.0-5.4 & 24.0 & 391 & 16.3 \\ 2 & 3.5-4.0 & 76.5 & 924 & 12.1 \\ 1 & 0-3.3 & 55.2 & 777 & 14.1\end{array}$

* Total depth of the bore hole is $139 \mathrm{~m}$.

** The recent sample is from four $5 \mathrm{~m}$ cores collected in 1983. 
therefore pollen-free. It had been stored as ice in plastic bags on the ice cap. This ice was broken into chips and dropped down the hole until it reached the required level. Filtered water was then lowered down the bore hole either in a particle-free plastic bag (1984) or in a particle-free hard plastic container. This water permeates the ice chips and refreezes to form an ice plug at a predetermined level in the bore hole. The process takes several hours. More filtered water was then lowered down the bore hole to form a priming medium for the immersion heater. The vertical extent, not volume, of the melt water determines the length of the increment which will form the bulk sample.

An immersion heater was lowered into the water, to begin melting the ice as soon as possible after the priming liquid was released over the plug. A $3 \mathrm{~kW}$, single-element, $240 \mathrm{~V}$ heater was used in 1984 , but a device containing twenty $90 \mathrm{ohm}$ heaters (ten pairs of firerods wired in series across $240 \mathrm{~V}$ to produce $3.2 \mathrm{~kW}$ ), similar to the head of the CRREL drill, was used in 1985 and 1986. Fifty litres of water are produced down the bore hole after approximately $5 \mathrm{~h}$ of heating.

A pump/tank device was used to extract the melt water. This device consists of a melt tank, suction tube and vacuum pump similar to the melt-tank/pump section of the CRREL thermal drill. In 1984, before such a device was available, the melt water was extracted by lowering two 1 litre plastic bottles on a wire-line, and drawing the water up, 1-2 litres at a time. The melt water was emptied into a 15 litre stainless-steel pressure tank. It was then filtered through $8 \mu \mathrm{m}$ pore-size, $47 \mathrm{~mm}$ diameter cellulose acetate filters. Each individual filter was then stored in a Petri dish. Depth measurements at each stage of the procedure were made on a weighted wire-line, with reference to the bottom of the bore hole. Periodically, the hole was calipered and the bottom depth ascertained by reference to wall irregularities which had been measured previously.

The lowermost sample (no.1, Fig.1) was obtained by filtering 1979 drill melt water. Nine samples of various levels in the lowermost $3.5 \mathrm{~m}$ were amalgamated to give a single pollen spectrum covering most of the dirty ice. The sample sizes, depths and the pollen concentrations in them are listed in Table II.

\section{Laboratory}

The laboratory method developed for processing pollen from ice-core and snow samples has been described at length in Bourgeois and others (1985) and Bourgeois (1986). Briefly, it consists of overnight soaking of each filter in hydrofluoric acid in order to dissolve any siliceous microparticles. The residue is then poured into a Nalgene filter holder, where it drains through a $50 \mathrm{~mm}$ diameter, $8 \mu \mathrm{m}$ pore-size Nuclepore filter, which retains the pollen grains. The Nuclepore type of filter is used because it retains the pollen on an even surface rather than "in depth"; this facilitates later identification of the pollen grains. After rinsing with particle-free water, the Nuclepore filter, still in place in the Nalgene holder, is washed with glacial acetic acid to dehydrate the filter. An acetolysis miture of sulphuric acid and acetic anhydride is then used to dissolve any remnants of the original cellulose acetate filter and to stain the pollen grains on the Nuclepore filter. The filter is then placed on two juxtaposed glass slides and cut into two. A few drops of glycerine and a slide cover are added to each of the two slides. All pollen grains in the sample are counted because the entire filter is examined under the microscope.

\section{Contamination}

Each stage of the field and laboratory procedures has been monitored for contamination. All equipment used in the field procedures was rinsed until the water used for rinsing was found to be pollen-free. On six occasions a water-filled container was left exposed in the field hut where the filtering and tank-emptying procedures were carried out. Six pollen grains were found over a $24 \mathrm{~h}$ period, two during a $10 \mathrm{~h}$ period and none in four $5 \mathrm{~h}$ periods.

In the Ottawa laboratory all samples were processed in a Class 100 clean-air cabinet. The air in the laboratory outside the cabinet was filtered on several occasions and found to be pollen-free. Contamination in field and laboratory procedures therefore seems unlikely.

\section{RESULTS}

Palynological studies generally consider changes in pollen spectra with depth at various sites in terms of changes in the composition of the surrounding vegetation. These may be further intepreted in terms of climatic change. In the case of ice cores from the High Arctic, all pollen grains are (strictly speaking) exotic, because no vegetation grows on the ice cap from which the core is taken. All pollen grains come from sources at distances varying from tens to thousands of kilometres from the core site. Changes in pollen concentration and spectra with increasing depth in the core reflect a complex interplay of changing air-mass trajectories, changing pollen sources and changing types of vegetation, or elimination of all vegetation within those sources. We therefore use the term exotic for pollen produced south of the High Arctic (as defined in Polunin 1951) and the term regional for pollen that is produced by the High Arctic tundra; some of it is produced at elevations below the ice cap on Ellesmere Island itself. Within the High Arctic, vegetation is generally sparse or confined to sheltered lower slopes and valley bottoms (Polunin 1951, Edlund 1983). There are a few areas, mainly on Ellesmere Island, which support an almost continuous vegetation cover (Porsild 1957, Savile 1964, Brassard and Beschel 1968, Babb and Bliss 1974, Soper and Powell 1985). These areas may be contributing most of the regional pollen grains to the drill-site area.

Pollen grains of most herbaceous plants (with the exception of Ambrosia, Artemisia, Chenopodiaceae and a few others) and pollen of a few woody plants (Salix, Dryas, and Ericaceae species) are all included in the regional pollen spectrum. Tree pollen and the pollen of a few herbaceous species (see above) are exotic to the region, with sources in most instances more than $1000 \mathrm{~km}$ from Agassiz Ice Cap. These exotic grains can be important in pollen spectra from tundra areas (Birks 1973), but are especially significant in ice cores, where they generally represent more than $50 \%$ of the total pollen.

Our results are presented in terms of pollen-grain concentrations per litre of melt water, rather than as deposition rates, because we do not know past snow-accumulation rates. Percentage diagrams have not been compiled, because we prefer, at this early stage of the bulk-sampling work, to discuss the results only in very general terms. Additionally, our purpose is served by

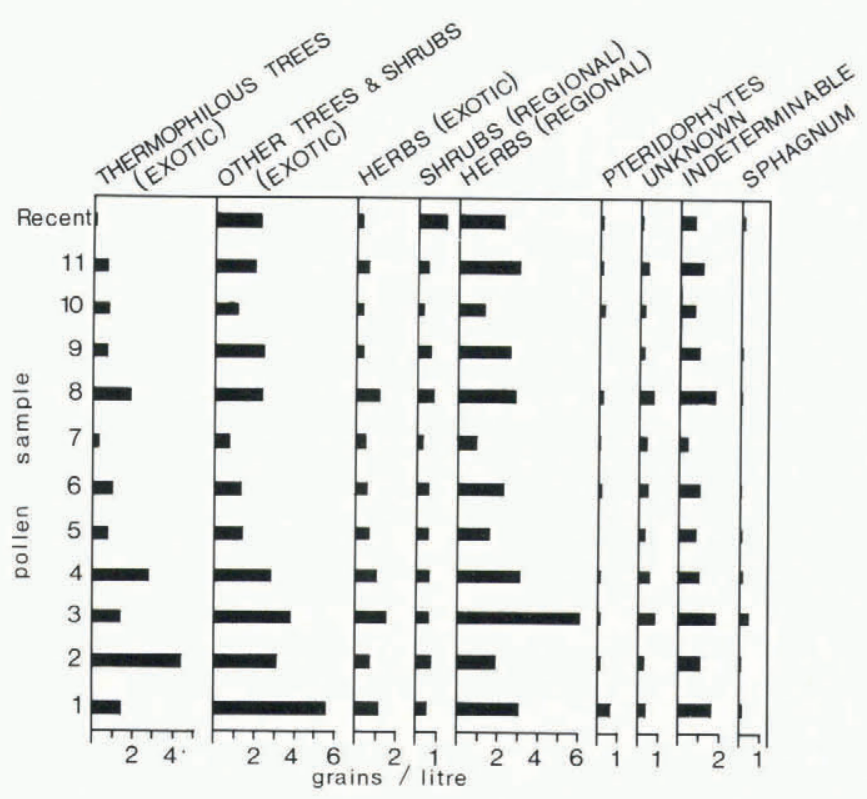

Fig.2. Exotic and regional pollen concentrations plotted by sample number. 
Sample no.

\begin{tabular}{rrrrrrrrrrrrr} 
& 1 & 2 & 3 & 4 & 5 & 6 & 7 & 8 & 9 & 10 & 11 & Recent \\
\hline Acer & 18 & 25 & 2 & 20 & 1 & 4 & 1 & 5 & 2 & 2 & 2 & 4
\end{tabular}

Carya

Corylus

Fagus

Fraxinus

Juglans

Ostrya

Quercus

Tilia

Tsuga

Ulmus

$\begin{array}{llllllllllll}46 & 197 & 18 & 142 & 14 & 24 & 12 & 44 & 17 & 15 & 15 & 1\end{array}$

$\begin{array}{lllllllllllll}\text { Alnus } & 76 & 61 & 22 & 49 & 16 & 14 & 9 & 32 & 15 & 8 & 18 & 47 \\ \text { Betula } & 51 & 68 & 16 & 60 & 13 & 17 & 4 & 28 & 32 & 16 & 11 & 44\end{array}$

\section{Gymnosperms}

Juniperus

2

Picea

$$
\begin{array}{rrrrrrrrrrrr}
1 & 16 & 17 & 19 & 3 & 3 & 6 & 12 & 14 & - & 3 & - \\
14 & 4 & 2 & 6 & - & 1 & 1 & - & - & - & 3 & 7 \\
159 & 38 & 14 & 79 & 11 & 7 & 5 & 9 & 10 & 6 & 13 & 69 \\
2 & 42 & 17 & 18 & 3 & 1 & - & 9 & 11 & 7 & 9 & 1
\end{array}
$$

Pinus

$\begin{array}{rrrrrrrrrrrr}14 & 4 & 2 & 6 & - & 1 & 1 & - & - & - & 3 & 7 \\ 159 & 38 & 14 & 79 & 11 & 7 & 5 & 9 & 10 & 6 & 13 & 69\end{array}$

Populus

Shepherdia
canadensis

Ambrosia

$\begin{array}{llllllllllll}42 & 39 & 24 & 49 & 12 & 11 & 11 & 9 & 4 & 4 & 10 & 17\end{array}$

Artemisia

Chenopodiaceae

38

Leguminosae

Nymphaea

Plantago

Potamogeton

Rumex

Sparganium

Thalictrum

Typha latifolia

Umbelliferae

Dryas

Ericaceae

Salix

$28 \quad 49$

814

$\begin{array}{lll}7 & 3 & 2\end{array}$

Caryophyllaceae 


\begin{tabular}{|c|c|c|c|c|c|c|c|c|c|c|c|c|}
\hline Cruciferae & 7 & 1 & 2 & 2 & 1 & - & - & 1 & - & 3 & - & \\
\hline Cyperaceae & 8 & 48 & 90 & 113 & 30 & 33 & 18 & 56 & 68 & 21 & 31 & \\
\hline Epilobium & 1 & - & - & - & - & - & - & 1 & - & - & - & \\
\hline Gramineae & 38 & 36 & 29 & 38 & 5 & 13 & 3 & 20 & 17 & 10 & 34 & \\
\hline Liguliflorae & - & - & 1 & 1 & 1 & - & - & - & - & - & - & \\
\hline Oxyria digyna & 3 & 12 & 2 & 22 & 1 & 19 & 1 & 7 & 4 & 2 & 5 & 2 \\
\hline Pedicularis & - & - & - & - & - & - & - & 1 & - & - & - & \\
\hline Primulaceae & - & - & - & 3 & - & - & - & - & - & - & - & \\
\hline Ranunculaceae & 1 & 12 & 4 & 17 & 3 & 5 & 4 & 7 & 3 & 2 & 1 & \\
\hline Rosaceae & 10 & 17 & 5 & 46 & 2 & 2 & 3 & 4 & - & 1 & 5 & 22 \\
\hline Saxif ragaceae & 14 & 8 & 10 & 16 & 3 & 1 & 2 & 4 & 1 & 3 & 13 & 26 \\
\hline Tubuliflorae & 9 & 10 & - & 3 & 1 & 3 & - & 4 & - & - & 3 & 3 \\
\hline Botrychium & 1 & - & - & - & - & - & - & 1 & - & - & - & 1 \\
\hline Dryopteris & 2 & 1 & - & - & - & - & - & - & - & - & 1 & - \\
\hline Equisetum & 1 & - & - & - & - & - & - & - & - & - & - & - \\
\hline $\begin{array}{l}\text { Lycopodium } \\
\text { annotinum }\end{array}$ & 1 & - & - & - & - & - & - & - & - & - & - & - \\
\hline $\begin{array}{l}\text { Lycopodium } \\
\text { lucidulum }\end{array}$ & 3 & - & - & - & - & - & - & - & - & 1 & - & - \\
\hline $\begin{array}{l}\text { Lycopodium } \\
\text { selago }\end{array}$ & - & 2 & - & 1 & - & - & - & - & - & - & - & 1 \\
\hline Lycopodium sp. & 3 & - & - & - & - & - & - & - & - & 1 & - & - \\
\hline Osmunda & 4 & - & - & - & - & - & - & - & - & - & - & - \\
\hline Monolete spore & 9 & 1 & 1 & - & - & - & - & - & - & 3 & - & - \\
\hline Trilete spore & 4 & 3 & 1 & 3 & - & 1 & 1 & 2 & - & - & - & 5 \\
\hline Indeterminable & 90 & 79 & 44 & 86 & 25 & 34 & 14 & 46 & 36 & 23 & 34 & 51 \\
\hline Unknown & 18 & 27 & 19 & 40 & 8 & 12 & 9 & 26 & 7 & 10 & 11 & 9 \\
\hline Sphagnum & 6 & 3 & 10 & 4 & 1 & 1 & - & 1 & 1 & - & 1 & 16 \\
\hline Total & 777 & 924 & 391 & 984 & 185 & 236 & 121 & 419 & 282 & 160 & 251 & 555 \\
\hline Litres & 55.2 & 76.5 & 24.0 & 83.6 & 31.7 & 33.9 & 36.7 & 39.2 & 37.3 & 34.5 & 30.6 & 77.8 \\
\hline
\end{tabular}

investigating only the absolute concentration of each pollen type at each level. The changing concentration of one type of grain alters the percentage of all the others even if their concentration remains the same. This serves to complicate the picture of what is perhaps, in palynological terms, the unique case of ice-core studies. Thus we discuss the results mainly in terms of fluctuations of the regional and exotic concentrations (Fig.2). However, the numbers of each pollen type at every level are listed in Table III.

\section{DISCUSSION}

\section{Sections $A$ and $B$}

There is a surprising lack of variation between the pollen concentrations in early Holocene (section A) and Wisconsinan (section B) ice. In fact, the sample from the late glacial period (no.8, upper part of section B) shows higher total pollen concentrations than all the samples from
Holocene ice (Fig.1). This is puzzling but may be due to the effect on the various pollen-deposition processes of time-varying snow-accumulation rates, both at the drill site and along pollen-carrying air-mass trajectories (i.e. drier or wetter air masses between source and site). There is evidence elsewhere (e.g. Lorius and others 1985, Yiou and others 1985) that snow-accumulation rates in the polar regions were substantially lower (by factors of 1.5-3) during the glacial period, especially during the period of maximum glacial extension, $18 \mathrm{ka}$. However, we have found no significant relationship between pollen concentrations and accumulation rates in the Queen Elizabeth Islands. Thus we cannot be sure that any change in snow-accumulation rate at the drill site would dilute or concentrate the pollen. What is more likely is that rain and snow-precipitation rates between pollen source and deposition site have affected the final pollen-deposition rate. This is because heavier precipitation causes more "wash-out" of pollen grains before 
reaching the drill site. The anomalously high pollen concentration in the late glacial-period ice (no.8) may be partly due to much lower continental precipitation rates at that time. In addition, different air-mass trajectories may have allowed more distant transport of pollen grains However, it means we cannot identify the glacial, or non-glacial, origin of ice from its total pollen concentration alone. More work clearly needs to be done on the pollen spectra themselves.

Maple (Acer), oak (Quercus) and elm (Ulmus) pollen grains are quite common in all the samples except the most recent (Table III). During the late glacial period in North America these three arboreal types were restricted to the southern part of the continent (Whitehead 1973). This indicates that there were very long trajectories then. From previous work (summarized in Koerner and Fisher 1985), and the appearance and number of filters required to filter the pollen grains at this level (no.8, Fig.1), we know that a very high concentration of microparticles does occur in this ice. The same high concentrations of microparticles have also been found in Antarctic and Greenland late glacial-period ice (e.g. Thompson 1977). High particulate, as well as high pollen, concentrations in the ice indicate high turbidity then, and probably low precipitation rates along most of the air-mass trajectory.

\section{Sections $C$ and $\mathbf{D}$}

High pollen concentrations in section C, coupled with less negative $\delta$ values than in section $B$ ice above it, a first suggest an interglacial-period origin for the ice. However, the $\delta$ values in the A77 and A79 of section C show a trend from Holocene-like values at the bottom of the section to "colder"-than-Holocene values at the top. The $\delta$ trend, together with continuing high pollen concentrations, suggests a progressively cooling climate where the pollen source remains ice-free. Lower sea-levels in OIS $5 \mathrm{a}$, b and c may be attributed to ice build-up on Baffin Island and the Labrador-Ungava peninsula (Aksu 1985, Andrews and others 1985, Vincent and Prest 1987, Ruddiman and others 1980). In our studies of present-day regional variations in pollen concentrations in the surface snow it was concluded that there is not a simple south-to-north transport of pollen grains (Bourgeois and others 1985). The Labrador-Ungava peninsula is an unlikely pollen source (see also Barry and others 1981), so that ice build-up there would not directly affect pollen deposition rates in our drill-site areas.

High pollen concentrations in the deepest sample (no.1, section D), coupled with the least negative $\delta$ values in the whole A79 core, strongly suggest that this ice has formed from surface snow which was deposited in a warmer climate than that of today. The conclusion of Gemmell and others (1986), that the dirt particles in section D are too large to have been blown on to the Agassiz Ice Cap, does not apply during the initial growth stages of the ice cap, when it was still very small. In the Canadian Arctic islands today some of the small ice caps do in fact show large surface agglomerations of dirt, especially in locations close to their margins. However, how do we explain the absence of this section in all the other Arctic island cores? We would stress here that the basal layers of all the cores, even if they all have an interglacial-period origin, need not have formed at the same time. Section D of A79 may represent a period of both accumulation and ablation conditions, with the former dominating only slightly. The drill-site area (A79) would generally be unglaciated, except for small summit areas with ice caps growing by the formation of superimposed ice. More widespread glaciation, with fewer periods of ablation, would expand the ice-covered areas and drastically reduce the incidence of the wind transport of large particles to the drill-site areas. At this stage the D72 and D73 cores, $5^{\circ}$ of latitude farther south, would begin their growth. For example, Meighen Island ice cap began its growth at a time of general cooling (in this case during the Holocene), so that most of Meighen Island became snow/ice-covered. Thus the basal layers of the Meighen Island ice cap do not contain ice as dirty as section D of A79, but are more similar to the basal ice of cores D72, $\mathrm{D} 73$ and A77. What is most puzzling is why A77 is lacking section D, as its location only $1 \mathrm{~km}$ from the A79 drill site should mean, spatially, a very closely related origin for the basal ice in cores A79 and A77. The problem may be one of ice dynamics rather than climatic history.

Taking sections C and D together, we see continuously high pollen concentrations, with an overall trend of decreasing $\delta$ values from the base of the dirty ice to the B-C boundary. Section D and some of the lowermost section $C$ ice in A79 show the bubble-free characteristics of superimposed ice. The lowermost parts of section $\mathrm{C}$ in the D72, D73 and A77 cores have the same texture. We propose that the bubble-free sections represent the early stages of ice-cap growth, when the mode of accumulation was superimposed ice. As the climate cooled and the ice thickened, the drill sites rose above the firn line, so that ice with a higher bubble fraction formed from firn. The ice caps therefore began their growth in a climate warmer than today, probably toward the end of the last interglacial. As our cores are from the tops of two of the larger ice caps, the Arctic islands may have been ice-free during an earlier part of the same interglacial.

This hypothesis means there is no ice older than the last interglacial in the cores, which contradicts the melt / freeze-on explanation of the origin of the ice in section $D$. It also equates the $B-C$ boundary with the onset of the main part of the last glacial period, about $65-70 \mathrm{ka}$, as originally proposed (Paterson and others 1977). The problem with equating the $\mathrm{B}-\mathrm{C}$ boundary with the end of OIS 5e, i.e. considering both sections $C$ and $D$ as interglacial, is that the core sequence then goes almost directly from interglacial to full glacial conditions. Koerner and Fisher (1979) suggested that the steep $\delta$ gradient at the $\mathrm{B}-\mathrm{C}$ boundary in the D72 and D73 cores is due to shear between two types of ice with different rheological properties (soft ice in section B and harder ice in section C). Shearing may drastically have thinned the transition stage from interglacial- to full glacial-period ice (although the latter is the soft ice) and may explain the abrupt change from interglacial- to full glacial-period ice. This could be the case with the D72 and D73 cores, which are several kilometres down the flow line. However, the trend of increasingly negative $\delta$ values between the bed and the B-C boundary, and proximity to the top of the flow line, makes shearing a much less likely mechanism for ice attrition in the A79 core (Fig.1).

There is a consistent discrepancy between melt-tank and bulk-sample pollen concentrations in ice at similar depths, where the melt tank gives much lower concentrations. The discrepancy can only partly be explained in terms of poor resolution of the melt-tank values. We can discount contamination of the bulk samples in the field, as some of the high values in the bulk samples are of pollen (e.g. elm) which now occurs at very low concentrations in surface snows. We have also shown previously that our pollen samples are not contaminated during laboratory preparation. We had found that trace-metal concentrations in melt-tank water are much lower than those in very carefully prepared core samples. Thus some unknown process seems to be "cleaning" the melt-tank water, either as it is produced or during its transport to the melt tank. We now feel, because of the compatibility between the more easily obtained surface-snow pollen concentrations and down-bore-hole bulk concentrations, that the melt-tank values are generally too low.

\section{CONCLUSIONS}

While pollen concentrations do not on their own provide an unequivocal climatic signature, they do show potential for interpretation in terms of climate when viewed together with other variables, especially $\delta$ values. Thus, because of the association of high pollen concentrations in the basal dirt layer of the 1979 core with very "warm" $\delta$ values, we feel that the surface origin of this ice in a period of warmer climate than today is a more acceptable hypothesis than the melt/freeze-on one. However, we cannot be absolutely certain which hypothesis is correct. Hopefully, analysis of more bulk samples and cores taken at the top of the flow line in both 1984 and 1987 will allow us to resolve the problem of the mode of origin of all the ice below the $\mathrm{B}-\mathrm{C}$ boundary. In addition, comparison of various suites of samples should indicate which of the various pollen-sampling methods is the most appropriate. 


\section{ACKNOWLEDGEMENTS}

Some of this work was done while we were members of the Polar Continental Shelf Project (PCSP). The same group supported our field operations throughout the project. All oxygen-isotope samples were analysed at the Geophysical Institute, University of Copenhagen, under the direction of Dr W Dansgaard. This work would not have been possible without their co-operation. We would also like to acknowledge very thorough criticism by an anonymous referee, which caused us to change our view of the results substantially and, hopefully, improved the quality of the paper. This paper is contribution no.53086 of the Geological Survey of Canada.

\section{REFERENCES}

Aksu A E 1985 Climatic and oceanographic changes over the past 400,000 years: evidence from deep-sea cores on Baffin Bay and Davis Strait. In Andrews J $\mathrm{T}(e d)$ Quaternary environments; eastern Canadian Arctic, Baffin Bay and western Greenland. Boston etc, Allen and Unwin: 181-209

Andrews J T and six others 1985 Land/ocean correlations during the last interglacial transition, Baffin Bay, northwestern North Atlantic: a review. Quaternary Science Reviews 4: 333-355

Babb T A, Bliss L C 1974 Susceptibility to environmental impact in the Queen Elizabeth Islands. Arctic 27(3): 234-237

Barry R G, Elliott D L, Crane R G 1981 The paleoclimatic interpretation of exotic pollen peaks in Holocene records. Review of Palaeobotany and Palynology 33: $153-167$

Birks H J B 1973 Modern pollen rain studies in some Arctic and Alpine environments. In Birks $\mathrm{H} \mathrm{J}$ B, West R G (eds) Quaternary plant ecology. Oxford, Blackwell: $143-168$

Bourgeois J C 1986 A pollen record from the Agassiz Ice Cap, northern Ellesmere Island, Canada. Boreas 15(4): 345-354

Bourgeois J C, Koerner R M, Alt B T 1985 Airborne pollen: a unique air mass tracer, its influx to the Canadian high Arctic. Annals of Glaciology 7: 109-116

Brassard G R, Beschel R E 1968 The vascular flora of Tanquary Fiord, northern Ellesmere Island, N.W.T. Canadian Field Naturalist 82(2): 103-113

Dansgaard W and 6 others 1982 A new Greenland deep ice core. Science 218(4579): 1273-1277

Edlund S A 1983 Bioclimatic zonation in a high Arctic region: central Queen Elizabeth Islands. Geological Survey of Canada Paper 83-1A: 381-390

Gemmell A M D, Sharp M J, Sugden D E 1986 Origin of debris and basal ice from the Agassiz Ice Cap, Ellesmere Island, Arctic Canada. Earth Surface Processes and Land forms 11: 123-130

Herron S, Langway C C Jr 1979 The debris-laden ice at the bottom of the Greenland ice sheet. Journal of Glaciology 23(89): 193-207

Johnsen S J, Dansgaard W, Clausen H B, Langway C C Jr 1972 Oxygen isotope profiles through the Antarctic and Greenland ice sheets. Nature 235(5339): 429-434 (Corrigenda 236(5344): 249)

Koerner R M, Fisher D A 1979 Discontinuous flow, ice texture and dirt content in the basal layers of the Devon Island ice cap. Journal of Glaciology 23(89): 209-222

Koerner R M, Fisher D A 1985 The Devon Island ice core and the glacial record. In Andrews J $\mathrm{T}$ (ed) Quaternary environments; eastern Canadian Arctic, Baffin Bay and western Greenland. Boston etc, Allen and Unwin: 309-327

Koerner R M, Fisher D A, Paterson W S B 1987 Wisconsinan and pre-Wisconsinan ice thicknesses on Ellesmere Island, Canada: inferences from ice cores. Canadian Journal of Earth Sciences 24(2): 296-301

Lorius C and 6 others 1985 A 150,000-year climatic record from Antarctic ice. Nature 316(6029): 591-596

McAndrews J H 1984 Pollen analysis of the 1973 ice core from Devon Island ice cap, Canada. Quaternary Research 22(1): $68-76$

Paterson W G B and 7 others 1977 An oxygen-isotope climatic record from the Devon Island ice cap, Arctic
Canada. Nature 266(5602): 508-511

Polunin N 1951 The real Arctic: suggestions for its delimitation, subdivision and characterization. Journal of Ecology 39(12): 308-315

Porsild A E 1957 Illustrated flora of the Canadian Arctic Archipelago. National Museum of Canada Bulletin 146

Ruddiman W F, McIntyre A, Niebler-Hunt V, Durazzi J T 1980 Oceanic evidence for the mechanism of rapid northern hemisphere glaciation. Quaternary Research 13(1): $33-64$

Savile D B O 1964 General ecology and vascular plants of the Hazen Camp area. Arctic 17(4): 237-258

Shackleton N J, Opdyke N D 1973 Oxygen isotope and palaeomagnetic stratigraphy of equatorial Pacific core V28-238: oxygen isotope temperatures and ice volumes on a $10^{5}$ and $10^{6}$ year scale. Quaternary Research $3(1)$ : 39-55

Soper J H, Powell J M 1985 Botanical studies in the Lake Hazen region, Northern Ellesmere Island, Northwest Territories, Canada. Ottawa, National Museums of Canada (Publications in Natural Sciences 5)

Thompson L G 1977 Variations in microparticle concentration, size distribution and elemental composition found in Camp Century, Greenland, and Byrd Station, Antarctica deep ice cores. International Association of Hydrological Sciences Publication 118 (General Assembly of Grenoble 1975 - Isotopes and Impurities in Snow and Ice): 351-364

Vincent J-S, Prest V K 1987 The Early Wisconsinan history of the Laurentide ice sheet. Géographie Physique et Quaternaire 41: 199-213

Whitehead D R 1973 Late-Wisconsin vegetational changes in unglaciated eastern North America. Quaternary Research 3(4): 621-631

Yiou F, Raisbeck G M, Bourles D, Lorius C, Barkov N I $1985{ }^{10} \mathrm{Be}$ in ice at Vostok, Antarctica during the last climatic cycle. Nature 316(6029): 616-617 